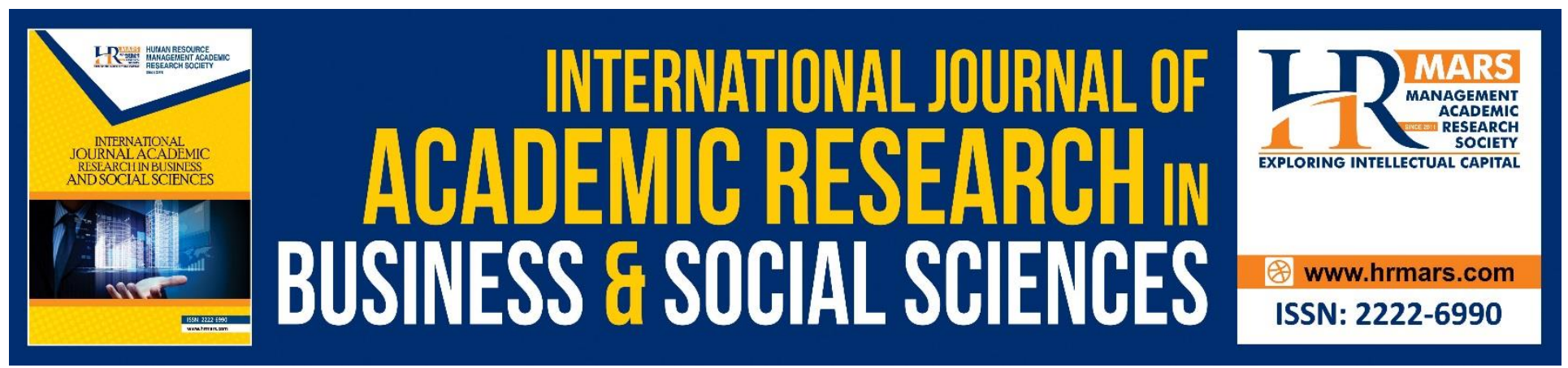

\title{
The Comparison of the Effectiveness of Conventional and Multimedia Approaches in Nurturing Student's Achievement towards Additional Mathematics
}

Mohankathan, Roslinda Rosli, Effandi Zakaria

To Link this Article: http://dx.doi.org/10.6007/IJARBSS/v9-i6/6064

DOI: 10.6007/IJARBSS/v9-i6/6064

Received: 18 April 2019, Revised: 19 May 2019, Accepted: 02 June 2019

Published Online: 25 June 2019

In-Text Citation: (Mohankathan, Rosli, \& Zakaria, 2019)

To Cite this Article: Mohankathan, Rosli, R., \& Zakaria, E. (2019). The Comparison of the Effectiveness of Conventional and Multimedia Approaches in Nurturing Student's Achievement towards Additional Mathematics. International Journal of Academic Research in Business and Social Sciences, 9(6), $1036-1042$.

Copyright: (C) 2019 The Author(s)

Published by Human Resource Management Academic Research Society (www.hrmars.com)

This article is published under the Creative Commons Attribution (CC BY 4.0) license. Anyone may reproduce, distribute, translate and create derivative works of this article (for both commercial and non-commercial purposes), subject to full attribution to the original publication and authors. The full terms of this license may be seen at: $\underline{\text { http://creativecommons.org/licences/by/4.0/legalcode }}$

Vol. 9, No. 6, 2019, Pg. $1036-1042$

Full Terms \& Conditions of access and use can be found at http://hrmars.com/index.php/pages/detail/publication-ethics 


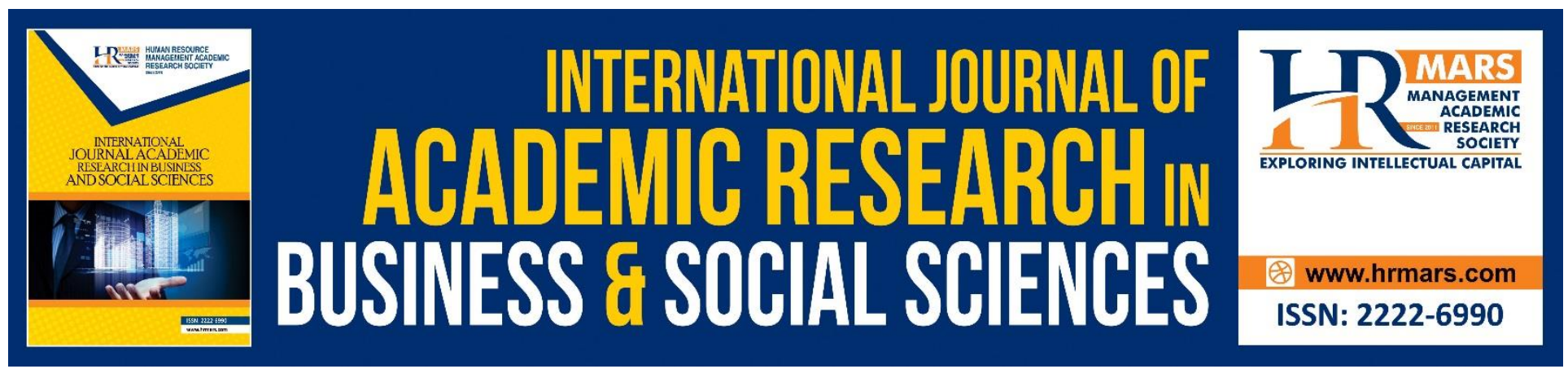

\title{
The Comparison of the Effectiveness of Conventional and Multimedia Approaches in Nurturing Student's Achievement towards Additional Mathematics
}

\author{
Mohankathan, Roslinda Rosli, Effandi Zakaria \\ Faculty of Education, The National University of Malaysia,Bangi, Malaysia. \\ Email:p76059@siswa.ukm.edu.my, roslinda@ukm.edu.my, effandizakaria@ukm.edu.my
}

\begin{abstract}
The aim of research is to compare the effectiveness of conventional and multimedia approach in students' achievement towards Additional Mathematics. The students' achievement towards Additional Mathematics is compared by gender and the interaction effect between groups and gender was studied. The instrument used in this research is achievement towards Additional Mathematics Lesson Scale (ATAMLS). A quasi-experimental research design with non-equivalent control group pre-survey and post survey was used. The participants of this research are Malaysian upper secondary four science stream students. Additional Mathematics is a compulsory subject in science stream in Malaysia. This research involved a total of 64 students, which are 31 male and 33 female students. The two-way ANOVA analysis showed that the effectiveness of group on the post ATAMLS mean score was not significant. It concluded that the level of students' achievement towards Additional Mathematics is same when experiment is done using conventional or multimedia approach. The effectiveness of achievement towards Additional Mathematics on gender was not significant. The analysis also showed that the interaction effect between group and gender in ATAMLS is not significant.
\end{abstract}

Keywords: Additional Mathematics, Multimedia Approach, Conventional Approach, Gender

\section{Introduction}

Additional Mathematics is a unique, interesting and compulsory subject in Malaysian upper secondary four science stream students. However, Additional Mathematics subject is considered to be difficult subject among Malaysian urban students (Ramirez, Chang, Maloney, Levine, \& Beilock, 2016). A better teaching method must be carried out to learn Additional Mathematics subject and this helps students in developing Additional Mathematics skills and promotes analytical mind among them. Better and appropriate teaching approach is vital and very useful to develop Additional Mathematics skills among students (Sun, Zaidatun Tasir, \& Jamalludin Harun, 2006). 
In 2003, the Ministry of Education (MOE) of Malaysia has introduced Information and Communication Technology (ICT) in teaching and learning. The use of ICT can help the school to build, modify and formulate knowledge, attitudes, feelings, beliefs and abilities of students. This will help students to acquire the 21st century skills in an easier way (Sharifah Nor \& Kamarul Azman, 2011).

The use of ICT in experimental teaching is a new method in Malaysia. For example, learning in smart schools emphasizes the use of ICT as a major component in the implementation of the teaching and learning activity ( Abd. Aziz, Subahan, Meerah, Halim \& Osman 2006). In this research our main aim is to compare students' achievement towards Additional Mathematics subject after Multimedia approach carried out in class room for experiment group using ICT technology in Circular Measures topic. Whereas the same topic taught using conventional approach for control group.

In a research conducted on a group of pre university students in London found that learning using computer simulations was able to change the mindset of students to be more motivated towards Circular Measures topic (Lawrence Spector, 2015). Due to the rapid changes in science and technology in todays world, new methods and techniques are needed in teaching Additional Mathematics.

\section{Multimedia Approach}

The Multimedia approach (MA) is defined as a computer-assisted teaching through the integration of computer simulations with teaching activities. Multimedia approach can change the concept of abstract teaching into concrete, linking the concepts learned with everyday life and students can learn at their own pace and needs (Stieff \& Wilensky, 2003). In the process of developing multimedia approach learning module, the researcher had built a storyboard before all the information and content is translated into a multimedia software.

\section{Conventional Approach}

Conventional approach (CA) was used long in MOE to teach Additional Mathematics direct from teacher to student. In this method the topic will be taught as fast as possible to finish the syllabus with the aim to achieve high score in year end examination. This method is used by most teachers without consider on the students ability and their knowledge. This method solely focus on text book and explanation by teacher in the classroom within given time frame.

\section{Methodology \\ Research Design}

This research uses quasi-experimental design to compare the effectiveness of multimedia approach (experiment group, EG) and conventional approach (control group, CG) on students' achievement towards Additional Mathematics in circular measure topic. This research is also aimed to compare student achievement towards Additional Mathematics with gender.

\section{Instrument}

Survey questionnaire was used in this research. The questionnaire is Achievement Towards Additional Mathematics Lessons Scale (ATAMLS) is developed by Kamisah (2010). This questionnaire was used before and after the treatment (Multimedia Approach \& Conventional Approach) to 
INTERNATIONAL JOURNAL OF ACADEMIC RESEARCH IN BUSINESS AND SOCIAL SCIENCES

Vol. 9, No. 6, June, 2019, E-ISSN: 2222-6990 (C) 2019 HRMARS

compare the students' achievement towards Additional Mathematics in circular measure topic in both classes. ATAMLS is an established survey questionnaire that was used in many studies. The Cronbach's alpha reliability for all subscales is between 0.81 to 0.87 .

\section{Sample}

A National Secondary School (NSS) in Malaysia was selected to participate in this research. A class was selected for multimedia approach (MA) while another class was engaged for conventional approach (CA). Both classes are science stream. Overall, this study involved a total of 64 participants with 31 males and 33 females.

\section{Data Analysis}

Data was analyzed using descriptive and inference statistic. Descriptive data was discussed by using mean, standard deviation and frequency. While inferential data was discussed by using two-way ANOVA.

\section{Research Results}

Descriptive statistics for 64 participants who involved in pre and post survey are as in Table 1.

Table 1 shows that the post mean score of achievement towards $A M(M=4.34, S D=0.74)$ is higher than the pre mean score achievements towards $A M(M=3.71, S D=1.16)$. This descriptive statistic also shows that the pre mean score of the $E G(M=3.41, S D=1.13)$ is higher than the mean score CG $(M=3.36, S D=1.18)$. On the other hand, in case of gender, the pre mean score of female $(M=3.41$, $S D=1.08)$ was higher than male $(M=3.34, S D=1.24)$. When compared to the pre mean score of male and female participants in the $C G$, the mean score of female $(M=3.59, S D=1.04)$ was higher than male $(M=3.04, S D=1.24)$. While the pre mean score for male and female participants in the $E G$, the male mean score $(M=3.47, S D=1.16)$ was higher than female $(M=3.31, S D=1.12)$. Referring to Table 4, the post mean score of $E G(M=4.25, S D=0.67)$ is higher than the $C G(M=4.11, S D=0.67)$. On the other hand, the post mean score of female $(M=4.24, S D=0.70)$ was higher than the male mean score $(M=4.18, S D=0.59)$. when compared to the post mean score for male and female participants in the $C G$, the mean score of $(M=4.15, S D=0.61)$ was higher than female participants $(M=4.13, S D=0.74)$. While the post mean score of male and female participants in $E G$, the mean score of female $(M=4.30, S D=0.72)$ was higher than the male $(M=4.24, S D=0.60)$. 
INTERNATIONAL JOURNAL OF ACADEMIC RESEARCH IN BUSINESS AND SOCIAL SCIENCES Vol. 9, No. 6, June, 2019, E-ISSN: 2222-6990 @ 2019 HRMARS

Table 1. Descriptive statistics pre and post survey ATAMLS mean score for group and gender

\begin{tabular}{llllll}
\hline ATAMLS & Group & Gender & M & SD & N \\
\hline Pre & Control & Male & 3.04 & 1.24 & 15 \\
& & Female & 3.59 & 1.04 & 16 \\
& Experiment & Male & 3.36 & 1.18 & 31 \\
& & 3.47 & 1.16 & 16 \\
& & Female & 3.31 & 1.12 & 17 \\
& Total & 3.41 & 1.13 & 33 \\
& Total & Male & 3.34 & 1.24 & 31 \\
& & Female & 3.41 & 1.08 & 33 \\
& & Total & 3.71 & 1.16 & 64 \\
\hline ATAMLS & Group & Gender & M & SD & N \\
\hline Post & Control & Male & 4.15 & 0.61 & 15 \\
& & Female & 4.13 & 0.74 & 16 \\
& & Total & 4.11 & 0.67 & 31 \\
& & Experimente & 4.24 & 0.60 & 16 \\
& & Male & 4.30 & 0.72 & 17 \\
& & Female & 4.25 & 0.67 & 33 \\
& & Total & 4.18 & 0.59 & 31 \\
& \multirow{3}{*}{ Total } & Male & 4.24 & 0.70 & 33 \\
& & Female & 4.34 & 0.74 & 64 \\
& & Total & & &
\end{tabular}

Table 2 shows two-way ANOVA analysis of the main effects and interaction effects on students' achievement towards Additional Mathematics for Circular Measures topic. The main effect of the group on the overall ATAMLS score was not significant, $F(1,63)=1.283, P=0.307$. However based on descriptive statistics, EG overall post mean score ATAMLS is higher than CG. So it can be concluded that student achievement towards Additional Mathematics in Circular Measures topic is better when Multimedia Approach is used. The main effects of gender on overall ATAMLS score were not significant, $F(1,63)=0.034, P=0.765$. However, based on descriptive statistics, the overall ATAMLS post mean score of female was higher than male. It can be concluded that the achievement of female participants towards Additional Mathematics is better than male participants. The results of the ANOVA analysis were also used to find interaction effect between group and gender based on overall score of ATAMLS. Interaction results obtained were also not significant, $F(1,63)=0.231, P=0.641$.

Table 2. Two-way ANOVA Analysis for main effect and interaction effect of Group and Gender

\begin{tabular}{llllll}
\hline Resources & $\begin{array}{l}\text { Sum of } \\
\text { squares }\end{array}$ & df & $\begin{array}{l}\text { Mean } \\
\text { Square }\end{array}$ & F & P \\
\hline Group & 0.604 & 1 & 0.604 & 1.283 & 0.307 \\
Gender & 0.014 & 1 & 0.014 & 0.034 & 0.765 \\
Group*Gender & 0.086 & 1 & 0.086 & 0.231 & 0.641 \\
\hline
\end{tabular}


INTERNATIONAL JOURNAL OF ACADEMIC RESEARCH IN BUSINESS AND SOCIAL SCIENCES

Vol. 9, No. 6, June, 2019, E-ISSN: 2222-6990 @ 2019 HRMARS

This shows that the groups' influence on the overall score of ATAMLS is not due to gender and the gender influence on overall score of ATAMLS is not due to groups.

\section{Discussion}

Descriptive analysis shows that the mean score of students' achievement towards Additional Mathematics for the EG is higher than the CG. This shows that the overall achievement of students towards Additional Mathematics is better if the teaching is carried out using Multimedia Approach as compared to Conventional Approach. Students' achievement towards Additional Mathematics for Circular Measures topic conducted using Conventional Approach is low because the learning method used by the teacher does not attract the students' interest. The difference in strategies that teachers used by conducting technology-assisted teaching has attracted and encouraged students to engage actively in learning. Students feel comfortable and enjoyable when they learn assisted by ICT.

Although the EG using the MALM to learn Circular Measures showed higher levels of student achievement towards Additional Mathematics the CG, but there was no significant effect on the achievement towards Additional Mathematics. This study demonstrates that learning activities regardless of Multimedia approach or Conventional Approach can help to reduce the gap between male and female achievement towards Additional Mathematics. In addition, appropriate teaching methods should be used o minimize gender gap performance. The method of teaching in classroom can ensure the improvement of the positive achievement of students towards Additional Mathematics.

\section{Conclusion}

Multimedia Approach and Conventional Approach did not show a significant difference on the students' achievements towards Additional Mathematics. There is no significant difference between gender and achievements towards Additional Mathematics and also no significant interaction effect between group and gender with achievements towards Additional Mathematics. Both methods have the same or similar impact on students' achievement towards Additional Mathematics. Even though the increase in the mean score is small, the use of the MALM has succeeded to change achievements towards Additional Mathematics. The difference in Multimedia Approach effectiveness on achievement towards Additional Mathematics may be more apparent if this Multimedia Approach is used for longer period. Achievement can be changed if an act is repeated for a longer time (William \& Radmila, 2008).Changes in learning the Circular Measures topic activities will cause the time that students use to perform activities to be longer. This will help students build positive attitudes towards Additional Mathematics. Further research is needed because the findings of this research show that the results are not significant between the CG and EG. There are some limitations that have been made in this research due to cost and time. Many improvements can be made so that further research that is implemented can give more effective results. The improvements are like; developing MALM for other topics, using different research locations, increasing the number of participants, using different methodology and analysis and increasing time of research. 
INTERNATIONAL JOURNAL OF ACADEMIC RESEARCH IN BUSINESS AND SOCIAL SCIENCES

Vol. 9, No. 6, June, 2019, E-ISSN: 2222-6990 (C) 2019 HRMARS

\section{References}

Ramirez, G., Chang, H., Maloney, E. A., Levine, S. C. \& Beilock, S. L. (2016). On the relationship between math anxiety and math achievement in early elementary school: The role of problemsolving strategies. Journal of Experimental Child Psychology 141 83-100. http://dx.doi.org/10.1016/j.jecp.2015.07.014

Sun, S. L., Tasir, Z., \& Harun, J. (2006). Penghasilan modul pembelajaran berasaskan teori beban kognitif untuk subjek teknologi maklumat dan komunikasi. 1st International Malaysian Educational Technology Convention1204-1213.

Nor, S. P. \& Azman, K. A. S. (2011). Tahap Kesediaan Penggunaan ICT dalam Pengajaran dan Kesannya Terhadap Hasil Kerja dan Tingkah Laku Murid Prasekolah. Jurnal Pendidikan Malaysia 36(1): 25-34.

Lawrence Spector. (2015). Radian Measures.www.themathpage.com/atrig/radian-measure.html

Stieff, M., \& Wilensky, U. (2003). Connected Chemistry, Incorporating Interactive Simulations into the Chemistry Classroom. Journal of Science Education and Technology, 12, 285. https://doi.org/10.1023/A:1025085023936

Kamisah, O., Tuan Mastura, T. S. \& Nurazdawati, M. A. (2010). Development and Validation of Malaysian 21 st Century Skills Instrument (M-21CSI) for Science Students. Procedia Social and Behavioral Sciences 9 (2010): 599-603.

Spector, P. E., Van Katwyk, P. T., Brannick, M. T., \& Chen, P. Y. (1997). When Two Factors Don't Reflect Two Constructs: How Item Characteristics Can Produce Artifactual Factors. Journal of Management, 23, 659-677. https://doi.org/10.1177/014920639702300503

William, C., \& Radmila, P. (2008). Frontier of Social Psychology Attitudes and Attitude Change. New York: Psychology Press. https://doi.org/10.1017/CB09781107415324.004 Yee, A. L. S. 